\title{
LAND CADASTRE DEVELOPMENT IN UKRAINE: ISSUES TO BE ADDRESSED
}

\author{
Andriy POPOV (iD ${ }^{*}$ \\ Land Management and Cadastre Department, Kharkiv National Agrarian University \\ named after V. V. Dokuchayev, Dokuchayevs'ke, Ukraine
}

Received 14 December 2018; accepted 18 September 2019

\begin{abstract}
Cadastral information is a key component for many land use functions and a core to the effective land markets, land use and sustainable development. These applications require up-to-date, reliable and complete data. This paper focuses on one aspect of land cadastre - identification of the objects of the cadastre. The characteristics and development of the existing cadastral system are discussed. We follow an empirical approach and propose an overview how and in what form the objects of state land cadastre are identified and registered in Ukraine. The paper analyses the problems associated with the plurality of the land cadastre objects. It is proposed to remove the registration numbers of the state land cadastre objects and new cadastral numbers of the land parcel from the legislation and return the legalization of the old cadastral number of the land parcel. The paper also underlines the necessity to consider the land parcel as a single object of the state land cadastre. Finally, it is proposed that the cadastral number of restrictions in the use of the land parcel will be an immense advantage in land registration and in visualisation the restrictions on the public cadastral map of Ukraine.
\end{abstract}

Keywords: land cadastre, land parcel, land registration, cadastral number, registration number, object, restriction.

\section{Introduction}

The land cadastre system is an important public institution for the effective land use management in a market economy. This system describes the interaction between the land parcels identification, land rights registration, valuation and taxation of land and property, as well as between the present and perspective land use (Bogaerts \& Zevenbergen, 2001; Enemark, Williamson, \& Wallace, 2005; Van der Molen, 2002). Therefore, a complete and objective cadastral information about the current land use is a key to the effective decision-making as for ensuring the guarantee of land rights and their protection, the rational use and protection of land, reducing the number of land disputes, stimulation and development of the land market, the fair taxation, the spatial planning and management of natural resources, the control over the use of the land. In the specific context, the land cadastre system contributes to enhancing social and political stability, improving the economy and the environmental conditions, improving the efficiency of state land administration and service delivery.

Considering the important role of the land cadastre in socio-economic development of the state and the necessity of Ukraine to integrate into the world economies, in 2013 there were significant and fundamental changes in the legislation as for conducting the land cadastre and the system of registration of property rights to the real property. Thus, for the first time for the years of Ukrainian independence, the Law of Ukraine "On State Land Cadastre" (Verkhovna Rada Ukrainy [VRU], 2011a) was adopted, which can be considered quite progressive even comparing with the standards of the developed countries. From that moment, the land cadastre was given the status of a single state geographic information system. Correspondingly, the amendments were made to the Law of Ukraine "On State Registration of Property Rights to Real Estate and their Restrictions" (VRU, 2004a) and a number of normative legal regulations were adopted that introduced a modern legal infrastructure for the creation of reliable databases concerning land and other real estate.

The State Land Cadastre (SLC) as a geographic information system should be able to store, manage and provide the data about all the registered land parcels and changes that occurred during their use in the form of spatial (cartographic) and textual information. Consequently, the land cadastre should be considered not only

*Corresponding author. E-mail: popov_andriy@knau.kharkov.ua 
as a land information system, but also as a land information resource for the providing of administrative services in the field of land tenure. One such service is the interactive information portal - the Public Cadastre Map of Ukraine - containing the complete and reliable information about the State Land Cadastre. The Public Cadastre Map of Ukraine (PCMU) is launched on the Internet and provides the easy access to the information that is open to the public. The main purpose of the PCMU is to provide the necessary (cadastral) information of a wide range of internal and external users.

An open access to a powerful monitoring tool (PCMU) gives an opportunity to affirm that the presence (visualisation) of cadastral information is not quite complete. More than $73 \%$ of the land parcels, among them approximately $65 \%$ occupy agricultural land (StateGeoCadastre, 2017), are registered in the system of SLC, and about $60 \%$ of the settlements boundaries are presented in the PCMU (Fedorovych, 2015). The data about the restrictions in land use are almost entirely absent. Thus, the current land cadastre has the signs of discreteness - a significant part of the land parcels is remained a sort of terra incognita for SLC. In this context, the SLC may lose the role of the main source of information for land management and land valuation in the course of the land policy implementation.

At present, there is a surprising scarcity of the researches as for identifying the main reasons of cadastral database incompleteness. Up to nowadays the majority of studies were focused only on technical issues such as the requirements for the accuracy of the land cadastre objects mapping (Baranovskyi, Karpinskyi, \& Liashchenko, 2009; Dutchyn, Hera, \& Syrotynska, 2013; Hermonova \& Lymareva, 2002; Trehub, 2014) or the functional requirements of the land information systems (Kovalyshyn \& Kryshenyk, 2018; Perovych, 2017; Taratula, 2016; Tretiak, 2012). We examine two main goals in this article. The first one is to identify the main reasons for the lack of a significant amount of information about the objects of the State Land Cadastre. The second goal is to give the ideas and recommendations as for the improving the maintenance of the State Land Cadastre as a geographic information system for registration and visualisation of the land data.

The limitations of the article mean that the significant topics are left aside:

- The problems of creating a unified cartographic basis for land cadastre;

- The lack of correspondence of the coordinate systems with mapping accuracy;

- The existence and correction of errors in the information about the State Land Cadastre;

- The absence of a unified approach to identifying a land parcels in the State Land Cadastre and in the Register of Property Rights to Real Estate;

- The lack of data as for land use restrictions in the State Land Cadastre;

- The problems in the land cadastre administration and access to the cadastral information;
- The absence of a mechanism for the data generalization about the objects of the State Land Cadastre with the regard to land records;

- The introduction of unified software approaches to the formation of geospatial data.

\section{Methodology and theoretical framework}

The materials of the research are the legislative base as for the conducting the State Land Cadastre; the cadastral information obtained from the official sources of the State Service of Ukraine for Geodesy, Cartography and Cadastre; the electronic land information received from the Public Cadastral Map of Ukraine; and scientific works of Ukrainian and foreign authors. The research is based on the methodical principles of scientific abstraction, synthesis and analysis of the elements.

The article is structured in the following way: a brief characteristics of the cadastral system in Ukraine (including the structure of the cadastral system and cadastral activities) will be given at the beginning; the concept of the State Land Cadastre will be analysed in the second part; the objects of the State Land Cadastre (including their classification and the identification features) are given in the third part; the obtained results and their impact on the future of the State Land Cadastre system are discussed in the fourth part and, finally, the conclusions and recommendations are given in the last part. Although the article is a separate study of Ukrainian experiences, but it provides useful information for other countries with developing land cadastre systems.

\section{The results of the research}

\subsection{The cadastral system in Ukraine}

The land cadastre as a totality of documentary registers about natural, economic and legal status of land was carried out on the territory of modern Ukraine beginning from the earliest times. However, the formation of the current land cadastral system took place mainly under the influence of the land reform, which has being continued in the country since 1991. During the first years of Ukraine's independence, to a great extent the land cadastre has inherited the "Soviet" approaches to land registration, which have not been completely eliminated until now.

The cadastral system in Ukraine concerns both cadastre and land registration. The legislation provides for the creation and maintenance of the whole number of state cadastres such as:

- Land cadastre (VRU, 2011a);

- Water cadastre (Vodnyi kodeks, 1995);

- Forest cadastre (Lisovyi kodeks, 1994);

- Cadastre of deposits and minerals occurrence (VRU, 2004b);

- Cadastre of the country's health resorts natural areas (VRU, 2000); 
- Cadastre of territories and objects of the nature reserve fund (VRU, 1992);

- Fauna cadastre (VRU, 1999);

- Flora cadastre (VRU, 2001);

- Cadastre of natural medicinal resources (VRU, 2000);

- Regional cadastres of natural resources (Postanova Kabinetu Ministriv Ukrainy [PKMU], 2001);

- Urban planning cadastre (VRU, 2011b);

- Cadastre of anthropogenic emissions from the sources and the absorption of hotbed gases (PKMU, 2006);

- Cadastre of radioactive waste storage (VRU, 1995).

Unofficially all these cadastres are called branch cadastres. Conducting of the branch cadastres are done under the control of different ministries and agencies. It led to the existence of duplication (overlapping) of the information, inaccurate and incomplete data, the lack of a unified cartographic basis, etc. The SLC is the basis for conducting other branch cadastres (Zemelnyi kodeks, 2001) (see Figure 1).

The State Service of Ukraine for Geodesy, Cartography and Cadastre ("The StateGeoCadastre") is the central executive body that is responsible for the implementation and administration of the State Land Cadastre. It carries out the state policy in the sphere of topographic and geodetic as well as cartographic activities and land relations and also in the sphere of the State Land Cadastre. According to the Law of Ukraine "On the State Land Cadastre", the State Enterprise "The Centre of State Land Cadastre" is an administrator of the SLC and it is responsible for carrying out the activities for establishment and maintenance of the SLC software, for technical and technological support, and preservation and protection of data contained in the SLC (VRU, 2011a). The State Enterprise "The Centre of State Land Cadastre" belongs to the sphere of management of the StateGeoCadastre.

The land register is divided between two open to general use state registers: 1) the State Register of Property Rights to Real Estate ("The Real Property Register") that is under the control of the state registration subjects accredited by the Ministry of Justice and 2) the State Land Cadastre. The two registers differ in their predestination but they are interrelated. The Real Property Register, in the first turn, includes the information about the title to ownership and any restrictions, including the right to use the land and the right to its mortgage - the interests in land (e.g. rights, restrictions and responsibilities). The land cadastre focuses only on the land parcels. The main function of SLC is to identify each land parcel using its unique cadastral number and provide mainly the spatial (physical data) information that is specific to each such a land parcel.

Therefore, the SLC together with the state registration subjects are responsible for the initial land parcels registration; and the state registration subjects and notaries are responsible for the secondary land registration/title registration (transfer of land rights) (see Figure 2). The

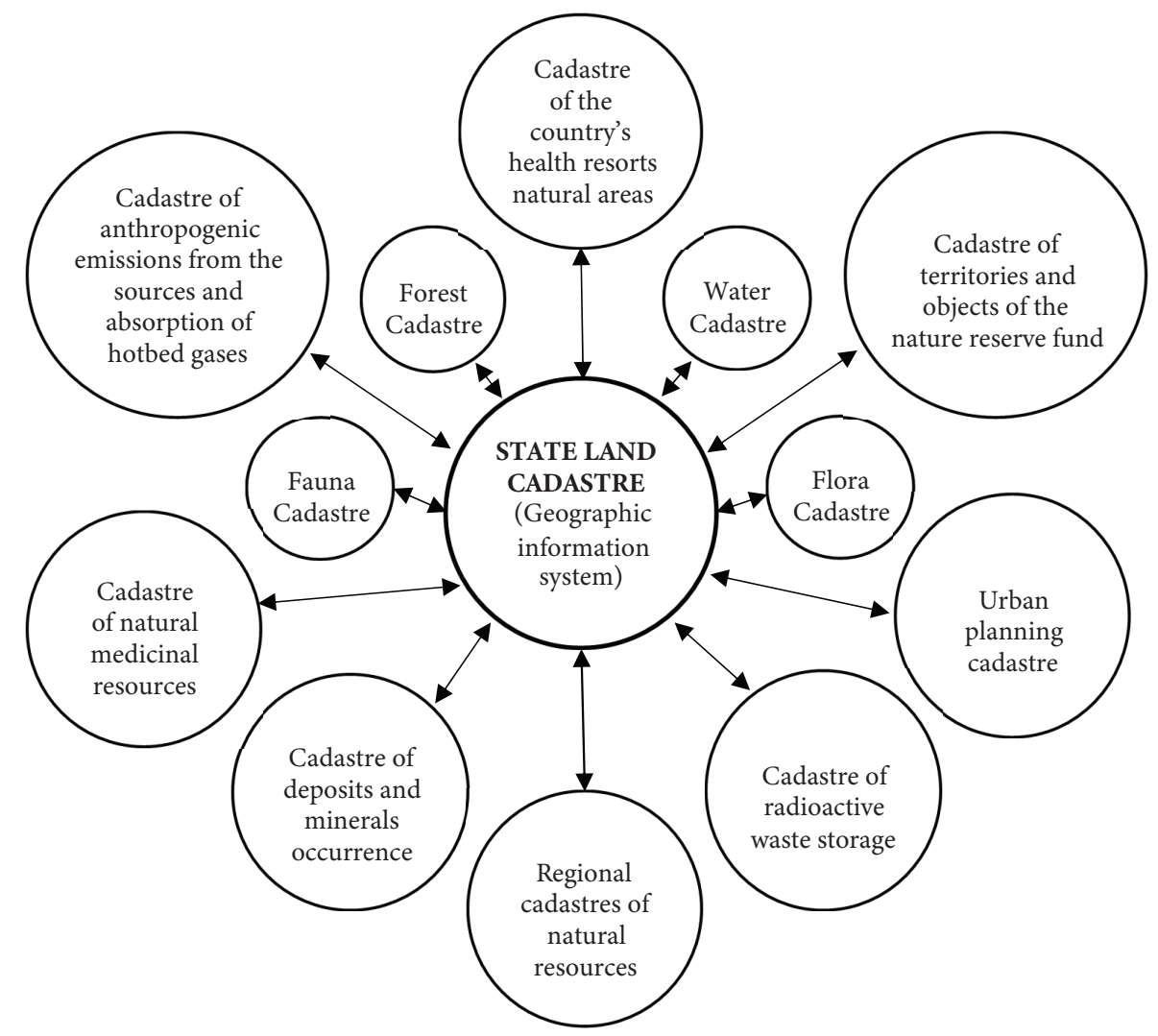

Figure 1. Cadastral system of Ukraine 
two central databases (the Real Property Register and the State Land Cadastre accordingly) are technically linked in providing an integrated on-line service for the official use.

The state registration of land parcels and property rights is obligatory but it is conducted on a voluntary basis. Thus, the land registration is carried out sporadically, depending on the citizens' needs in legalizing the corresponding rights to a land parcel. A basic unit is a two-dimensional parcel.

A new wave of cadastral works in rural areas has started since 2001, when the special legislation on the division of the former Soviet agricultural collective farms and their transfer to private ownership had been introduced ("The Privatization Law"). Most of the land parcels officially intended for agricultural production was privatized. About $70 \%$ of lands have been transferred to private ownership. In most cases the cadastral information, collected in the context of land parcels, which has been registered since 2013 is accurate and reliable. The records made before 2013 should be clarified because of different measurement techniques, different coordinate systems, and map scales which were used during the cadastral works. Simultaneously with the State geodetic reference system of coordinates USC-2000, two more systems, SC-42 and SC-63, are used: they are the bases for 1146 local coordinate systems (Medyns'ka, 2017). Different techniques and coordinate systems are the obstacles for conversion the analogue cadastral data and maps into digital ones and they are the reason of various technical errors existing in the land cadastral data.

New information technologies increase the level of cadastral service; bring a platform for improving the data quality and the effective access of citizens to the information. A website has been created by the StateGeoCadastre to provide cadastral e-service for the individuals and certified land surveyors (e-cadastre).

\subsection{The concept of state land cadastre and its objects}

By given the definition, the law-maker tried to cover the multipurpose destination of the cadastre, but thereby he created the basis for the ambiguous interpretation of the main object of land registration. It can become an obstacle to effective management and development of the state land cadastre. An example can be found when considering the concept of "land". Within the limits of some legislation the land is defined as "the main national wealth", and, within the limits of the other, it is defined as "the most important part of the environment", as it is seen from Table 1 below. The description of such an ambiguous terminology will facilitate greater understanding of the issues and clear understanding of the SLC essence and also will promote the adoption of the appropriate unambiguous legislation.

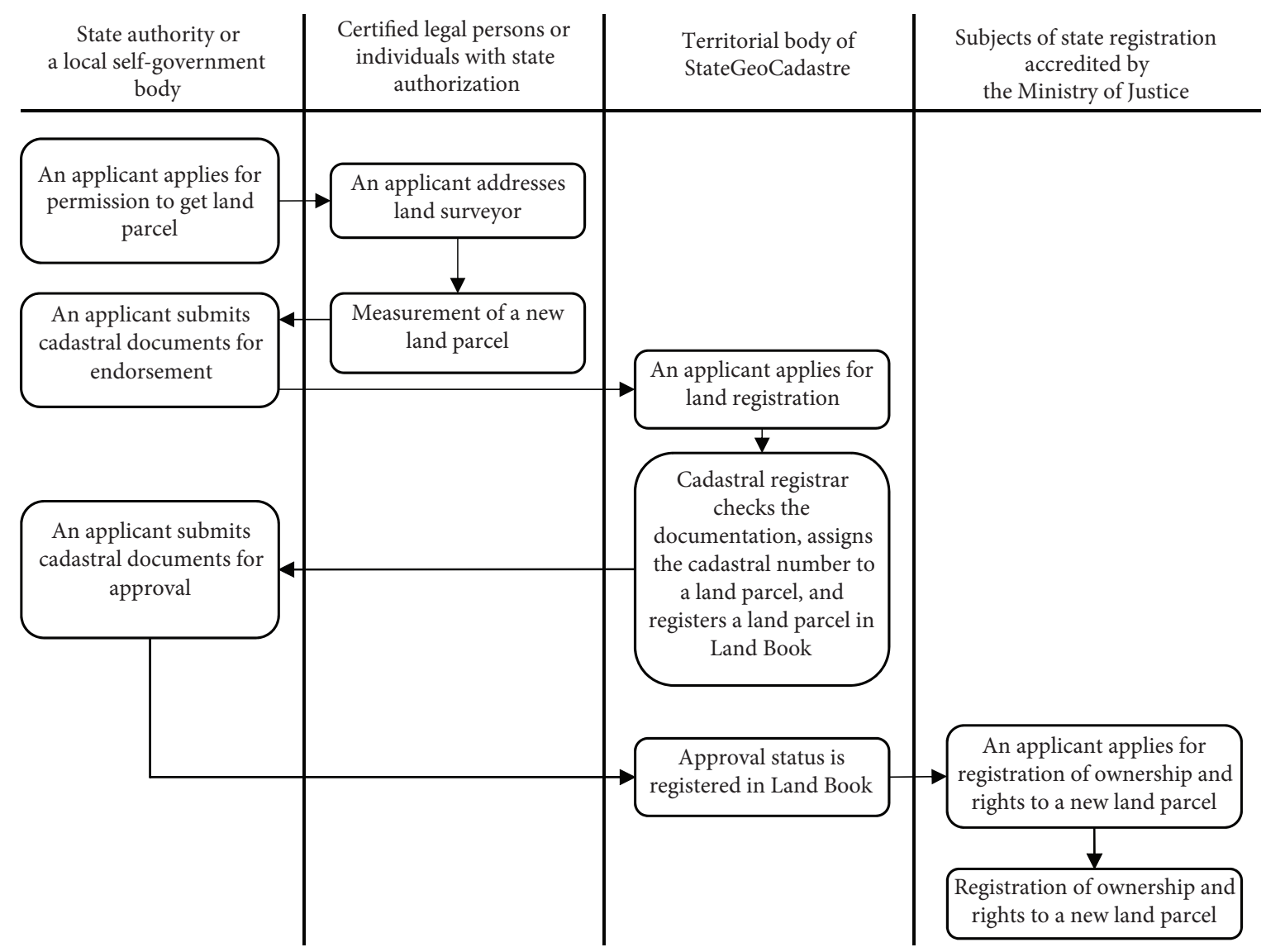

Figure 2. The simplified diagram of the initial state land registration in Ukraine 
Table 1. Definitions of land

\begin{tabular}{|l|l|l|}
\hline \multicolumn{1}{|c|}{ Legislation } & \multicolumn{1}{|c|}{ Term } & \multicolumn{1}{c|}{ Definition } \\
\hline Constitution of Ukraine & "land" & is the main national wealth (Constitution of Ukraine, 1996). \\
\hline Land Code of Ukraine & "land of \\
Ukraine" & $\begin{array}{l}\text { is all land within its territory, including islands and the lands occupied by water } \\
\text { objects, which are classified according to their main purpose (Zemelnyi kodeks, 2001). }\end{array}$ \\
\hline $\begin{array}{l}\text { Law of Ukraine "On Land } \\
\text { Protection" }\end{array}$ & "land" & $\begin{array}{l}\text { is a surface of land with soils, minerals and other natural elements that are organically } \\
\text { interconnected and function together with it (VRU, 2003). }\end{array}$ \\
\hline $\begin{array}{l}\text { State standard 26640-85 } \\
\text { 13. "Earth. Terms and } \\
\text { determinations" }\end{array}$ & "land" & $\begin{array}{l}\text { is the most important part of the environment characterised by space, relief, soil, } \\
\text { vegetation, minerals, water and is the main means of production in agriculture, } \\
\text { as well as the spatial base for the placement of sectors of the national economy } \\
\text { (Gosudarstvennyj komitet SSSR po standartam, 1989). }\end{array}$ \\
\hline
\end{tabular}

The concept of "land", depending on the context, is used in many ways in the general spectrum of the natural sciences (like a planet, a surface, a soil); in economic science (as a means of labour, the main means of production and spatial operational basis in agriculture); in jurisprudence and social sciences (purpose, forms of ownership, legal land use, etc.); in environmental sciences (as a component of the environment and the condition of human life). Within one understanding, there can be various approaches to the filling of the concept of "land" with a specific content (Miroshnychenko, 2013).

The theory of land law and legislation stands for the opinion (Miroshnychenko, 2013) that "land" and "a land parcel" are correlated as a whole and a part. In other words, the land is the general object of legal land tenure, and a land parcel is a direct object which is individually defined as a part of the land territory. This means that the land parcel belongs to more general concept of "land", which can be divided into parts (parcels) and performs an appropriate function. Consequently, individualized signs or a sign of discretion are established only because of the definition and demarcation of the boundaries of the object, which, in its turn, allows characterizing the land in more details.

A land parcel is a basic unit for legal matters, access and control over the land, and land use decisions making. That is why the first and foremost importance is the appointing of a land parcel as the basis for conducting the State Land Cadastre, and as a geographic information system. The land parcel includes a geometric description which helps to link other records describing the nature of interests in land (e.g. rights, restrictions and responsibilities), the ownership or control over these interests, the value of the parcel, qualitative characteristics and its improvement. We believe that the Ukrainian State Land Cadastre should be a clear parcel-based land information system. The successful practice of the developed countries regarding cadastre conducting proves this statement (International Federation of Surveyors [FIG], 1995; UNECE, 2005).

It should be noted that in literature, including legislation, the concept of "land" mainly substitutes the term "land parcel". For example, the term "land lease" is often used instead of "lease of a land parcel", "land purchase and sale" is used instead of "purchase and sale of a land parcel", etc. Noting the formal incorrectness of such statements, it should be recognized that they are long-established and it is impossible to eradicate the use of the concepts of "land" and "land parcel" as the synonyms. Therefore, it remains to understand clearly in which cases the concept of "land" is used in its "basic" meaning, and in which - in the sense of "a land parcel” (Miroshnychenko, 2013, p. 15). However, the use of such an approach when interpreting these terms during formulating the definition of the State Land Cadastre is unacceptable.

Assuming the fact that the law-maker in the definition of the SLC under the term "land" meant the land parcel, then the regulations of Article 10 of the Law of Ukraine "On the State Land Cadastre" are not logical because there are four objects of land cadastre: the land within the state border of Ukraine; the land within the territory of the administrative-territorial units ${ }^{1}$; the restrictions of land use and the land parcel. Firstly, the land within the state border of Ukraine is considered exclusively as the information about the graphic representation (demarcation) of the state border and the description of the borderline, as well as the documents based on which the borders have been marked (VRU, 2011a, art. 12). Secondly, the lands within the territory of the administrative-territorial units are presented as their description (not according to the land parcels, but in general) with the indication to their total area in the context of the land category and land classification, as well as the general information about their qualitative and costly characteristics (VRU, 2011a, art. 13). Thirdly, the objects of the SLC have different identifications in the land cadastre. A registration number is an identifier of the land within the state border of Ukraine, the land within the territory of the administrative-territorial units and the restrictions in land use, while a cadastral number is an identifier of a land parcel. Therefore, in the definition of the SLC, the term "land" has a different meaning and is not considered as a synonym to the concept of "a land parcel".

\footnotetext{
${ }^{1}$ The administrative-territorial unit - is a compact part of the single territory of Ukraine, which is the spatial basis for the organization and activities of state authorities and local selfgovernment bodies (oblast, raion, city, districts in the city, village, and settlement).
} 
The structural elements of the registration number of the SLC objects (except for a land parcel) are shown in Figure 3.

\section{GCO : TGO : SNO,}

GCO - the group code of the State Land Cadastre object (3 numerical characters);

$T G O$ - the type of a certain group of the State Land Cadastre object (6 numerical characters);

SNO - the ordinal number of the State Land Cadastre object (10 numerical characters).

Figure 3. The structure of the registration number of the State Land Cadastre objects (PKMU, 2012, art. 28)

The structure of the "new" cadastral number of the land parcel is shown in Figure 4.

\section{NCZ : NCQ : NLP,}

$N C Z$ - the number of the cadastral zone, which is independent of the administrative-territorial division of Ukraine (12 numerical characters);

NCQ - the number of the cadastral quarter (3 numerical characters);

$N L P$ - the ordinal number of the land parcel within the cadastral quarter (4 numerical characters).

Figure 4. The structure of the "new" cadastral number of the land parcel (PKMU, 2012, art. 30 \& 34)

The registration number is given to the SLC objects when the information about these objects is documented into the SLC. The cadastral number is given to the land parcel during the state registration with the help of the special software. The information about the registration numbers of the SLC objects and cadastral numbers of the land parcels are kept in the State Land Cadastre during the whole period of their existence. In the case of division or amalgamation of the land parcel (changes in shape and area), a new cadastral number is given to the land parcel and the previous number is cancelled. The legislation does not appoint the list of conditions under which the registration number of the SLC object is changed.

Despite the fact that the new legislation of the SLC was adopted more than six years ago, the software for giving the registration and "new" cadastral numbers has not been developed yet. Accordingly, the registration and cadastral

\section{CUATDU : NCZ : NCQ : NLP,}

CUATDU - the code for a unit of the administrative-territorial division of Ukraine (10 numerical characters);

$N C Z$ - the number of a cadastral zone (2 numerical characters);

$N C Q$ - the number of a cadastral quarter within the cadastral zone (3 numerical characters);

$N L P$ - the ordinal number of the separate land parcel within the cadastral quarter (4 numerical characters).

Figure 5. The structure of the "old" cadastral number of the land parcel (PKMU, 2010) numbers were not given to any SLC objects. Instead, in practice, the "old" cadastral number (which was used before the adoption of the Law of Ukraine "On State Land Cadastre" and Procedure for conducting state land cadastre) is still being used and is given only to the land parcels.

The "old" cadastral number of a land parcel has a hierarchical identification system and is shown in Figure 5.

The key difference between the "new" cadastral number of the land parcel and the "old" one is that the new structure of the cadastral number does not reflect the belonging of the land parcel to any administrative-territorial unit within the state border of Ukraine.

There exists the situation that de jure, there is one cadastral number, but de facto another, "old" number is used in the land registration.

\subsection{Land registration}

The state registration of the land parcel is the inclusion into the State Land Cadastre the information about the formation of the land parcel and giving a cadastral number to it by introducing the Land Book for this land parcel. The formation of the land parcel means measuring its size and boundaries and including this information into the State Land Cadastre. The land parcel is formed beginning from the moment of giving a cadastral number to it.

The state cadastral registrar is the person responsible for the state registration of the land parcels, maintenance and keeping the Land Books. A Land Book is a cadastral documentation which contains the following information about the land parcel: the cadastral number; size; location; types of land use; purpose of land use; the normative monetary value; the information about the restrictions in the use of the land parcel; the information about the boundaries of the part of the land parcel covered by an easement and/or the sublease contract; the cadastral plan of the land parcel; the date of the land parcel state registration; the information about the land-use planning documentation, on which basis the state registration of the land parcel has been done; the information about the owners (users) of the land parcel in accordance with the data about the registered property rights in the Real Property Register; and the data concerning soil appraisal. The Land Book is being kept in paper and electronic (digital) versions and closed in case of cancelling the state registration of the land parcel.

The information about the objects of the SLC (except for the land parcel) and changes in them is included into the State Land Cadastre and is taking place when the application and the corresponding documentation on the land-use planning are put in. However, the cadastral legislation does not specify where exactly the information about these SLC objects is entered, how it is systematized and what cadastral documentation is attached to it. It should be emphasized that the information about the SLC objects is included, but not registered by introducing the data into the Land Book. The Land Book is introduced for the land parcels only. 
To be fair, we should note that the documentation on land-use planning, which is the basis for including the information about the objects of the SLC into the land cadastre and the registration of the land parcel, is attached to the state cadastral registrar in the form of an electronic document as XML file format via Unicode (UTF-8).

Therefore, there arises the question of the advisability of introducing the registration numbers, the "new" cadastral numbers and the SLC objects (except for the land parcel) because they exist only in paper version (in the cadastral legislation) and do not have a practical application while keeping the SLC.

\section{Discussion and interpretation of the results obtained}

\subsection{Interpretation of the State Land Cadastre}

The appointment of four SLC objects (units) stipulated the legislative securing in the SLC to determine the detailed list of the information that should be recorded, stored and managed. However, such an approach gave birth to the new questions.

For example, why didn't the law-maker include in the definition of SLC the information about the legal regime of the land, the restrictions, cadastral zoning, the land parcel, etc.? Does it mean that this information is not required to be recorded in the SLC? The answer is absolutely not. The list and contents of the necessary information is changing with the development of the land cadastre. The information is not constant in time. Some data are excluded, others are supplemented. Consequently, it is not clear what purpose the law-maker pursued by including a clear list of the cadastral information in the definition of the SLC.

Further, what was the necessity to appoint the SLC as a geographic information system? It is known that in the future the cadastre will not be considered only as a geographical information system. The land cadastre will be focused towards the improving of spatial data supplying chains, building of integrated spatial models, and development of crowd sourcing capabilities and query-based spatial systems (Intergovernmental Committee on Surveying and Mapping [ICSM], 2014).

The legally defined definition of the SLC is unclear and inflexible due to the lack of understanding of a single object (unit) of the land cadastre and the overregulation of the information and technology component. That is why a new version of the definition of the SLC is proposed, namely: the State Land Cadastre is the land-parcel-based and up-to-date land information system containing the record about the interests in land within the area administered by the state body of the country. From this point of view, the land parcel is considered to be the smallest unit having the ownership. The land parcel may be called the legal parcel because the ownership of the land parcel is the legal basis for all dealings with land. It is important that this definition clearly defines a land parcel as a basic unit ("building-block") of the land cadastre and as a unique and uniform spatial reference system for the identification of all land parcels and this fact will help to integrate all the necessary spatially related data.

\subsection{Cadastral identification of the land parcels}

The main argument in introducing the new structure of the land parcel identification was that the "old" cadastral number of the land parcels (Figure 5) provided stability, reliability and immutability of the numbers (codes) of the administrative-territorial units of Ukraine. This feature of the cadastral number contradicted the regulations of the current land legislation, which regulated the possibility of changing the boundaries of the administrative-territorial units (districts, villages, settlements, and cities) (Kulynych, 2013). Certainly, such regulations are absolutely logical, since the settlements are developing and they need to expand (in some cases to narrow) their boundaries. However, the Ukrainian legislation does not determine the procedure for changing the cadastral numbers of the land parcels when changing the legal and/or post address, which, in its essence, means the prohibition to change the cadastral number. The only rule that changes the cadastral number of the land parcel is the subdivision or amalgamation of the parcel, that is, the change of its configuration and area.

Precisely for these reasons, a new identification system of the land parcel was proposed; it includes only the numbers of the cadastral zone, cadastral quarter and the land parcel. The main principle of a new approach is the independence of cadastral zoning of the administrativeterritorial division of Ukraine. It means that the cadastral number of the land parcels will not be changed in case of alterations of any administrative-territorial unit boundaries. Thus, the territory and the boundaries of the administrative-territorial units exist in parallel with the boundaries of the cadastral zones and do not depend on each other. Accordingly, such an approach demands carrying out the large-scale cadastral works throughout the Ukrainian territory as for marking the new boundaries of the cadastral zones and quarters, developing new index cadastral plans (maps) and changing the "old" cadastral numbers of land parcels (there are almost 17 million of them (Martyn, 2017)) to the new ones. It can be assumed that carrying out of such work requires the considerable financial costs and time and may cause great uncertainty in the status of the owners and users of the land parcels, and deprive them of their guarantee for the acquired rights to land.

However, since the adoption of the new cadastral legislation (in 2013), these cadastral measures have not been carried out. Neither the Resolution of the Cabinet of Ministers of Ukraine "On Approval of the Procedure for the State Land Cadastre" nor the other normative legal acts do not determine the mechanism to substitute the "old" cadastral numbers for the "new" ones.

Under such circumstances, it would be advisable to use a simpler and less costly way. It would be necessary 
to provide a legislative procedure and the content of the cadastral documentation for changing the cadastral number of the land parcel in case of transferring it from the structure of one administrative-territorial unit to another one with the preservation of the previous cadastral number as archival one. We believe that the existing procedure for the state registration of the land parcel (Figure 2) is completely meets these requirements.

\subsection{The registration number vs. the cadastral number}

As it has been already noted, according to the Procedure for the State Land Cadastre approved by Resolution of the Cabinet of Ministers of Ukraine, the registration number is given to the SLC objects (except for the land parcels) during including the data to the cadastre. It should be pointed out that the Law regarding the SLC does not provide the existence of such a registration number, and the procedure for its appointing has not been determined yet. The purpose of introducing the registration numbers to the SLC objects (except for the land parcels) remains unclear for several reasons.

Firstly, the registration number is given to the land within the state border of Ukraine in order to include and map the statistic (since the state border is not changing very often) information concerning the description of the border only (its graphic representation, the names of the neighbouring foreign states, the description of the borderline and the demarcation data). Therefore, it is unclear whether it should be one registration number across the entire state border, or it should be divided into several parts and for each of them a separate registration number should be given.

It is clear that the state border is the basis for the creation of the appropriate state geodetic and cartographic bases for the purpose of the SLC creation, but still there are some doubts about the feasibility of appointing a separate registration number to the border or its parts. It is sufficient for the cadastre that the state border is mapped in the geographic information system according to the coordinates and it is the basis for conducting the land cadastre.

Secondly, the registration numbers are given to the land within the territory of the administrative-territorial units for the purpose of describing statistical cadastral information regarding the boundaries, the total area in the context of the land categories and types of land use, the qualitative and appraisal characteristics of the oblasts, raions, villages, settlements, and cities. It is enough for the cadastre that the boundaries of each administrative-territorial unit are introduced into the geographic information system according to the coordinates.

Thirdly, the registration numbers are given to the restrictions in the land use without any reference to the land parcel which these restrictions are concerned. Thus, the land cadastre contains the information about the existence of certain restrictions in the land use (type, boundaries, and size) but there is no data as for the certain land parcel which these restrictions are applied to. This may have serious negative consequences while using the land parcels in short and long-terms. In addition, the restrictions in the land use are not displayed graphically in the geographic information system of the SLC, and, accordingly, they are not mapped on PCMU. This is unacceptable.

Considering the land cadastre as a geographic information system based on the land parcels and taking into the account the above-mentioned arguments, we may have good grounds to assert that the introducing the registration numbers for the SLC objects is not advisable. The land parcel must be a single unit of including the information into the SLC. We propose to add the information about the boundaries of the state border of Ukraine and the territories of the administrative-territorial units to the SLC as the state geodetic and cartographic basis for the SLC conducting (without giving the registration numbers). In addition, it is expedient to add the information about the restrictions in the land use to the SLC (including easement, emphyteusis and superficies) with the reference to the land parcels.

The proposed structure of the restrictions cadastral number in the use of the land parcel (located within its boundaries) is based on the "old" cadastral number of the land parcel and is shown in Figure 6.

\section{CUATDU : NCZ : NCQ : NLP : CRUL : PNO,}

CUATDU - the code for a unit of the administrative-territorial division of Ukraine (10 numerical characters);

$N C Z$ - the number of a cadastral zone (2 numerical characters); $N C Q$ - the number of a cadastral quarter within the cadastral zone (3 numerical characters);

$N L P$ - the sequence number of a separate land parcel within the cadastral quarter (4 numerical characters).

CRUL - the code of restrictions in the use of the land parcel in accordance with Annex 6 of the Procedure for the State Land Cadastre (5 numerical characters);

$P N O$ - the ordinal number of restriction in the use of the land parcel (2 numerical characters).

Figure 6. The proposed structure of the cadastral number of restrictions in the use of the land parcel

The advantages of such a cadastral number structure are that there is no need to change the cadastral zoning in the country and to use the existing list of restrictions as for the use of the land parcels appointed by the procedure of the SLC conducting. Thus, the proposed approach can be easily adapted to the "new" cadastral number by adding two last structure elements (CRUL and PNO) of the restrictions cadastral number regarding the land parcel using (Figure 6).

The proposed cadastral number of restrictions in the use of the land parcel allows linking all the existing restrictions not only within one land parcel, but also with the other adjoining parcels through the use of spatiallybound data in the geographic information system. It gives the possibility to visualise (graphically represent) the restrictions concerning the use of the land parcel and to map them on PCMU. 
The state registration of the restrictions as for the land use in the system of the SLC should be carried out according to the same procedure as the registration of the land parcels with the inclusion the information about the restrictions into the Land Book (Figure 2). As a legal basis for such the requirements, the following regulations should be fixed in the cadastral legislation: the restrictions in the land use (including easement, emphyteusis and superficies) are set only to the registered (formed) land parcel; the restrictions in the land use are attached to the land parcel; if the land parcel is sold to a new owner, the restrictions in the land use are transferred together with the land parcel.

\section{Conclusions}

In this paper, we have examined the ambiguous understanding of the cadastral concept (judicial, fiscal, and multi-purpose) in Ukraine and the principles generally pursued. Such situation has led to different opinions about the cadastres and their application. This, in its turn, led to parallel implementation of a number of the branch cadastres, which serve as the information base for maintaining the basic State Land Cadastre. This fact demands the necessity for a large-scale formulation of the definition of the State Land Cadastre. The additions to the definition of the ambiguous concept of "land" led to the determination of four objects (units) of the state land cadastre and the plurality of the major land registration objects. It became the main reason for the non-viability of new approaches to the identification of the SLC objects determined by the cadastral legislation. The registration numbers of the objects of the SLC and the new cadastral numbers of the land parcels have not found their practical application in the development of cadastral documentation and in the inclusion of the associated information to the GIS system. Our research indicates that the information about the SLC objects (except for the land parcel) contains the generalized (statistical) information, and the "new" registration numbers of the SLC objects, as well as the "new" cadastral numbers of the land parcels, do not have their practical application. This fact led to the parallel existence of cadastral numbers of the old and new samples, which is inadmissible. Such a situation may introduce the elements of uncertainty and confusion in the identification system of the land parcels and have a negative effect on the reliability of the land information in the State Land Cadastre and the Real Property Register.

It is obviously that given shortcoming of the cadastral legislation should be eliminated as soon as possible. Firstly, at this stage of the development of the SLC it is proposed to return to the legal sphere the "old" cadastral number of the land parcel due to not only its practical use in the land cadastre, but also because the transition to the cadastral numbers of the new sample requires large financial and time costs for the replacement of all cadastral documentation and it may cause great uncertainty in the assurance of the acquired rights to the land. Secondly, it is expedient to exclude the registration numbers of objects of the SLC and cadastral numbers of the land parcel of a new sample from the legislation. We consider it advisable to add to the Procedure of the SLC the legal norm regarding the possibility of changing the cadastral number of the land parcel under the condition of its transferring from one administrative territorial unit to another according to the procedure of the state registration of the land parcel with the establishment of a clear list of the necessary cadastral documentation. Finally, the structure of the cadastral number of restrictions in the use of the land parcel has been suggested for visualisation and efficient interconnection of all existing restrictions in the use of the land parcels.

Our research has shown that the information about the objects of the SLC (except for the land parcel) contains the generalized (statistical) information, and the legally established procedure for their identification has not worked out. We propose to improve the current cadastral system by introducing a single (basic) object (unit) of the SLC and land registration, which is a land parcel. Accordingly, in the definition of the SLC it is proposed to make an accent that the land cadastre is the land-parcel-based information system.

\section{Funding}

This work was supported by the Kharkiv National Agrarian University named after V. V. Dokuchayev under scientific topic "Economic and legal bases of land management based on land-use planning and cadastral mechanisms" [0116U003885].

\section{Author contributions}

Conceptualization, AP; Methodology, AP; Validation, AP; Investigation, AP; Writing-Original Draft Preparation, AP; Writing-Review \& Editing, AP; Visualization, AP.

\section{Disclosure statement}

The author declares no conflict of interests.

\section{References}

Baranovskyi, V. D., Karpinskyi, Yu. O. (Ed.), \& Liashchenko, A. A. (2009). Topohrafo-heodezychne ta kartohrafichne zabezpechennia vedennia derzhavnoho zemelnoho kadastru. Vyznachennia ploshch terytorii. Kyiv: Naukovo-doslidnyi instytut heodezii i kartohrafii (in Ukrainian).

Bogaerts, T., \& Zevenbergen, J. (2001). Cadastral systems-alternatives. Computers, Environment and Urban Systems, 25, 325337. https://doi.org/10.1016/S0198-9715(00)00051-X

Constitution of Ukraine. (1996). Retrieved from http://zakon. rada.gov.ua/laws/show/254\%D0\%BA/96-\%D0\%B2\%D1\%80 (in Ukrainian).

Gosudarstvennyj komitet SSSR po standartam (1989). Zemli. Terminy ta vyznachennia HOST 26640-85 (ST SEV 4472-84): 
Derzhavnyi standart. Retrieved from http://zakon1.rada. gov.ua/laws/show/v3453400-85 (expired on 13.03.2017) (in Ukrainian).

Dutchyn, M., Hera, O., \& Syrotynska, I. (2013). Do pytannia tochnosti vyznachennia koordynat mezhovykh znakiv zemelnykh dilianok pry kadastrovykh znimanniakh. Heodeziia, kartohrafiia i aerofotoznimannia, 77, 85-88 (in Ukrainian).

Enemark, S., Williamson, I., \& Wallace, J. (2005). Building modern land administration systems in developed economies. Journal of Spatial Science, 50, 51-68.

https://doi.org/10.1080/14498596.2005.9635049

Fedorovych, V. (2015). Pravove zabezpechennia vstanovlennia (zminy) mezh naselenykh punktiv v Ukraini: problemy ta shliakhy yikhnoho vyrishennia. Visnyk Lvivskoho universytetu, 61, 395-401 (in Ukrainian).

Hermonova, E., \& Lymareva, E. (2002). Vlyianye korreliatsyonnykh zavisimostei mezhdu oshybkamy opredelenyia koordynat konturnykh tochek na tochnost' opredelenyia ploshchadei zemelnykh uchastkov. In Suchasni dosiahnennia heodezychnoi nauky ta vyrobnytstva (pp. 287-290) (in Russian).

Intergovernmental Committee on Surveying and Mapping. (2014). Cadastre 2034 - Powering Land \& Real Property. Cadastral Reform and Innovation for Australia - A National Strategy. Intergovernmental Committee of Surveying and Mapping, Canberra, Australia. Retrieved from https://www. sagi.co.za/documents/AustraliaCadastre_2034_Powering_ Land_and_Real_property.pdf

International Federation of Surveyors. (1995). The FIG Statement on the Cadastre. FIG publication No. 11. Retrieved from http://www.fig.net/resources/publications/figpub/pub11/figpub11.asp

Kovalyshyn, O. F., \& Kryshenyk, N. I. (2018). Improvement of methodic approaches to formation of legal restrictions while using land parcels in the system of the state land cadastre. Scientific Bulletin of UNFU, 28(4), 78-82 (in Ukrainian). https://doi.org/10.15421/40280414

Kulynych, P. F. (2013). Zemelni dilianky yak obiekt zemelno-reiestratsiinykh pravovidnosyn. Derzhava i pravo. Yurydychni $i$ politychni nauky, 60, 324-330 (in Ukrainian).

Lisovyi kodeks. (1994). Lisovyi kodeks Ukrainy vid 21.01.1994, No. 3852-XII. Retrieved from http://zakon.rada.gov.ua/laws/ show/3852-12 (in Ukrainian).

Martyn, H. (2017, July 3). Derzhavnyi zemelnyi kadastr: kudy ydemo? Agravery. Retrieved from http://agravery.com/uk/ posts/author/show? slug=derzavnij-zemelnij-kadastr-kudijdemo (in Ukrainian).

Medyns'ka, N. (2017, March 6). Nova systema heodezychnykh koordynat: hariacha profesiina dyskusiia na fakulteti zemlevporiadkuvannia. Retrieved from https://nubip.edu.ua/ node/29800 (in Ukrainian).

Miroshnychenko, A. M. (2013). Zemelne pravo Ukrainy (3rd ed.). Kyiv: Alerta (in Ukrainian).

Perovych, I. L. (2017). Kadastr v systemi administruvannia zemelnymy resursamy: teoriia i praktyka (Doctoral dissertation). Kyivskyi natsionalnyi universytet budivnytstva i arkhitektury, Kyiv, Ukraina (in Ukrainian).

Postanova Kabinetu Ministriv Ukrainy. (2001). Pro zatverdzhennia Polozhennia pro rehionalni kadastry pryrodnykh resursiv: Postanova Kabinetu Ministriv Ukrainy vid 28.12.2001, No. 1781. Retrieved from http://zakon.rada.gov.ua/laws/ show/1781-2001-\%D0\%BF (in Ukrainian).

Postanova Kabinetu Ministriv Ukrainy. (2006). Pro zatverdzhennia Poriadku funktsionuvannia natsionalnoi systemy otsinky antropohennykh vykydiv ta absorbtsii parnykovykh haziv, yaki ne rehuliuiutsia Monrealskym protokolom pro rechovyny, shcho ruinuiut ozonovyi shar: Postanova Kabinetu Ministriv Ukrainy vid 21.04.2006, No. 554. Retrieved from http://zakon. rada.gov.ua/laws/show/554-2006-\%D0\%BF (in Ukrainian).

Postanova Kabinetu Ministriv Ukrainy. (2010). Pro zatverdzhennia Tymchasovoho poriadku prysvoiennia kadastrovoho nomera zemelnii diliantsi: Postanova Kabinetu Ministriv Ukrainy vid 18.08.2010, No. 749. Retrieved from https://zakon.rada. gov.ua/laws/show/749-2010-\%D0\%BF (in Ukrainian).

Postanova Kabinetu Ministriv Ukrainy. (2012). Pro zatverdzhennia Poriadku vedennia Derzhavnoho zemelnoho kadastru: Postanova Kabinetu Ministriv Ukrainy vid 17.10.2012, No. 1051. Retrieved from http://zakon2.rada.gov.ua/laws/ show/1051-2012-ח (in Ukrainian).

StateGeoCadastre. (2017). Pidsumky roku: Kliuchovi pokaznyky diialnosti Derzhheokadastru. Retrieved from http://land.gov. ua/pidsumky-roku-kliuchovi-pokaznyky-diialnosti-derzhheokadastru/ (in Ukrainian).

Taratula, R. B. (2016). Rol derzhavnoho zemelnoho kadastru $\mathrm{v}$ informatsiinomu zabezpechenni systemy upravlinnia zemelnymy resursamy. Zbalansovane pryrodokorystuvannia, 1, 146-149 (in Ukrainian).

Trehub, M. V. (2014). Formuvannia prostorovoi informatsii dlia derzhavnoho zemelnoho kadastru. Dnipropetrovs'k: Natsionalnyi hirnychyi universytet (in Ukrainian).

Tretiak, A. M. (2012). Problemy rozvytku derzhavnoho zemelnoho kadastru v Ukraini yak systemy fiksatsii zemelnykh aktyviv. Zemleustrii, kadastr i monitorynh zemel, 1-2, 28-35 (in Ukrainian).

UNECE (2005). Land Administration in the UNECE Region: Development trends and main principles. Retrieved from: http:// www.unece.org/fileadmin/DAM/hlm/documents/Publications/landadmin.devt.trends.e.pdf

Van der Molen, P. (2002). The dynamic aspect of land administration: An often-forgotten component in system design. Computers, Environment and Urban Systems, 26, 361-381. https://doi.org/10.1016/S0198-9715(02)00009-1

Verkhovna Rada Ukrainy. (1992). Pro pryrodno-zapovidnyi fond Ukrainy: Zakon Ukrainy vid 16.06.1992, No. 2456-XII. Retrieved from http://zakon.rada.gov.ua/laws/show/2456-12 (in Ukrainian).

Verkhovna Rada Ukrainy. (1995). Pro povodzhennia $z$ radioaktyvnymy vidkhodamy: Zakon Ukrainy vid 30.06.1995, No. 255/95-BP. Retrieved from http://zakon.rada.gov.ua/laws/ show/255/95-\%D0\%B2\%D1\%80 (in Ukrainian).

Verkhovna Rada Ukrainy. (1999). Pro roslynnyi svit: Zakon Ukrainy vid 09.04.2001, No. 591-XIV. Retrieved from http:// zakon.rada.gov.ua/laws/show/591-14 (in Ukrainian).

Verkhovna Rada Ukrainy. (2000). Pro kurorty: Zakon Ukrainy vid 05.10.2000, No. 2026-III. Retrieved from http://zakon. rada.gov.ua/laws/show/2026-14 (in Ukrainian).

Verkhovna Rada Ukrainy. (2001). Pro tvarynnyi svit: Zakon Ukrainy vid 13.12.2001, No. 2894-III. Retrieved from http:// zakon.rada.gov.ua/laws/show/2894-14 (in Ukrainian).

Verkhovna Rada Ukrainy. (2003). Pro okhoronu zemel: Zakon Ukrainy vid 19.06.2003, No. 962-IV. Retrieved from http:// zakon4.rada.gov.ua/laws/show/962-15 (in Ukrainian).

Verkhovna Rada Ukrainy. (2004a). Pro derzhavnu reiestratsiiu rechovykh prav na nerukhome maino ta yikh obtiazhen: Zakon Ukrainy vid 01.07.2004, No. 1952-IV. Retrieved from http:// zakon.rada.gov.ua/laws/show/1952-15 (in Ukrainian).

Verkhovna Rada Ukrainy. (2004b). Pro nadra: Zakon Ukrainy vid 27.07.2004, No. 132/94-BP. Retrieved from http://zakon.rada. gov.ua/laws/show/132/94-\%D0\%B2\%D1\%80 (in Ukrainian). 
Verkhovna Rada Ukrainy. (2011a). Pro Derzhavnyi zemelnyi kadastr: Zakon Ukrainy vid 07.07.2011, No. 3613-VI. Retrieved from http://zakon.rada.gov.ua/laws/show/3613-17 (in Ukrainian).

Verkhovna Rada Ukrainy. (2011b). Pro rehuliuvannia mistobudivnoi diialnosti: Zakon Ukrainy vid 17.02.2011, No. 3038-VI. Retrieved from http://zakon.rada.gov.ua/laws/show/3038-17 (in Ukrainian).

Vodnyi kodeks. (1995). Vodnyi kodeks Ukrainy vid 06.06.1995, No. 213/95-BP. Retrieved from http://zakon.rada.gov.ua/laws/ show/213/95-\%D0\%B2\%D1\%80 (in Ukrainian).

Zemelnyi kodeks. (2001). Zemelnyi kodeks Ukrainy vid 25.10.2001, No. 2768-III. Retrieved from http://zakon.rada. gov.ua/laws/show/2768-14 (in Ukrainian). 